Syam S., Kumaji, Zuliyanto Zakaria. (2019). Potensi Anti Bakteri Mucus Ikan-Ikan Native di

Perairan Danau Limboto, Gorontalo, Indonesia. Jurnal Bioeksperimen. Vol. 5 (1) Pp. 55-60. Doi: 10.23917/bioeksperimen.v5i1.2795

\title{
POTENSI ANTI BAKTERI MUCUS IKAN-IKAN NATIVE DI PERAIRAN DANAU LIMBOTO, GORONTALO, INDONESIA
}

\author{
Syam S. Kumaji*, Zuliyanto Zakaria \\ Program Studi Biologi, Fakultas Matematika dan Ilmu Pengetahuan Alam, \\ Universitas Negeri Gorontalo \\ Jl. Jenderal Sudirman No. 06 Kota Gorontalo \\ *Email: syam_bio@ung.ac.id;
}

\begin{abstract}
Abstrak
Kerusakan danau Limboto, Gorontalo, Indonesia telah mempengaruhi fungsi ekologis danau sebagai habitat ikan-ikan native sehingga perlu dilakukan kajian tentang potensi ikan native danau Limboto. Penelitian ini bertujuan untuk mengetahui aktivitas antibakteri dari mucus ikan-ikan native danau Limboto. Pengujian aktivitas antibakteri dilakukan melalui metode diffusion test dengan mengukur diameter zona hambat yang terbentuk pada beberapa bakteri uji. Ekstraksi mucus dilakukan dengan menggunakan pelarut aquadest dan asam asetat sementara bakteri uji yang digunakan yakni Staphylococcus aureus dan Vibrio alginolyticus. Hasil penelitian menunjukkan bahwa aktivitas antibakteri mucus tertinggi terhadap bakteri $S$. aureus dengan pelarut aquadest adalah ikan Giuris cf. margaritacea (Hulu'u) sebesar $7.45 \mathrm{~mm}$ sedangkan dengan pelarut asam adalah ikan Stiphodon sp (Manggabai) sebesar $8.67 \mathrm{~mm}$. Selanjutnya aktivitas antibakteri mucus tertinggi terhadap $V$. alginolyticus pada pelarut aquadest adalah ikan Stiphodon sp. sebesar $6.85 \mathrm{~mm}$ dan pada pelarut asam adalah ikan Giuris cf. margaritacea sebesar $8.32 \mathrm{~mm}$. Aktivitas antibakteri dari mucus ikan Stiphodon sp (Manggabai) dan Giuris cf. margaritacea (Hulu'u) memiliki aktivitas antibakteri dengan kriteria sedang terhadap bakteri $S$. aureus dan $V$. alginolyticus.
\end{abstract}

Kata kunci: Ikan native, mucus, antimikroba, Danau Limboto

\begin{abstract}
Limboto Lake, Gorontalo, Indonesia has been ecological damage nowadays. It affected the habitat of native fish. So it is necessary to study the potential native fish from Limboto. This study aims was to determine the antibacterial activity of mucus native fish of Limboto Lake. Antibacterial activity testing was carried out through the diffusion test method by measuring the diameter of the inhibition zone formed in several test bacteria. Mucus extraction was carried out using aquadest and acetic acid solvents while the test bacteria used were Staphylococcus aureus and Vibrio alginolyticus. The results showed that the highest antibacterial activity of mucus against $S$. aureus bacteria with aquadest solvents was Giuris cf. margaritacea (Hulu'u) is $7.45 \mathrm{~mm}$ while acidic solvents are Stiphodon sp (Manggabai) fish of $8.67 \mathrm{~mm}$. Furthermore, the highest antibacterial activity of mucus against $V$. alginolyticus in aquadest solvents was Stiphodon sp. of $6.85 \mathrm{~mm}$ and in acid solvents is fish Giuris cf. margaritacea is $8.32 \mathrm{~mm}$. The antibacterial activity of fish mucus Stiphodon sp (Manggabai) and Giuris cf. margaritacea (Hulu'u) has antibacterial activity with moderate criteria for bacteria $S$. aureus and $V$. alginolyticus.
\end{abstract}

Keywords: Native fish, mucus, antimicrobial, Lake Limboto

\section{Pendahuluan}

Danau Limboto merupakan salah satu danau yang terletak di Provinsi Gorontalo dan secara geografis terletak pada $122^{\circ} 42^{\prime} 0.24^{\prime \prime}-123^{\circ} 03^{\circ}$ $1.17^{\prime \prime}$ BT dan $00^{\circ} 30^{\prime} 2.035^{\prime \prime}-00^{\circ} 47^{\circ} 0.49^{\prime \prime} \mathrm{LU}$. Areal danau ini berada pada dua wilayah yaitu $\pm 30 \%$ wilayah Kota Gorontalo dan $\pm 70 \%$ di wilayah Kabupaten Gorontalo dan menjangkau 5 Kecamatan. Danau Limboto, merupakan cekungan 
rendah atau laguna, yang merupakan muara sungai-sungai, diantaranya: Ritenga, Alo Pohu, Marisa, Meluopo, Biyonga, Bulota, Talubongo dan sungai-sungai kecil dari sisi selatan: Olilumayango, Ilopopala, Huntu, Hutakiki, Langgilo (Suwanto, et al., 2011).

Luas Danau Limboto sampai tahun 2007 sebesar 2.537,152 ha, dengan kedalaman sekitar 2 - 2,5 m sedangkan luas daerah tangkapan air Danau Limboto sekitar 900 km2. Pada tahun 1932 rata-rata kedalaman Danau Limboto 30 meter dengan luas $7.000 \mathrm{Ha}$, dan tahun 1961 rata-rata kedalaman Danau berkurang menjadi 10 meter dan luas menjadi 4.250 Ha. Sedangkan tahun 1990 2008 kedalaman Danau Limboto rata-rata tinggal 2,5 meter dengan luas $3.000 \mathrm{Ha}$ (Suwanto, et al., 2011).

Kondisi ekologis danau Limboto yang terus mengalami perubahan dari tahun ke tahun menyebabkan ancaman terhadap biota-biota yang hidup di perairan danau Limboto. Organisme memberikan respon terhadap tantangan ekologis lingkungan yang menyebabkan terjadinya variasi morfologi baik dalam tingkatan individu, populasi maupun spesies (Aydalina, 2015). Salah satu jenis biota yang memperlihatkan adanya respon terhadap lingkungan diantaranya adalah ikan

Beberapa ikan native yang dapat ditemui dikawasan Danau Limboto dan perairan sekitarnya merupakan ikan dari famili Gobiidae, Siluridae dan Eleotridae (Suwanto, et al., 2011). Lebih lanjut bahwa di danau Limboto ditemukan 3 spesies dari Famili Eleotridae yang berbeda secara morfologi dan genetik dibandingkan spesies yang sama di kawasan Danau Tondano (Aydalina, 2015). Salah satu substansi kimiawi yang dihasilkan oleh ikanikan native tersebut adalah mucus epidermal.

Mucus epidermal dihasilkan oleh sel mucus, terdiri dari air dan makromolekul pembentuk gel termasuk mucins dan glikoprotein lainnya. Lapisan mucus pada permukaan ikan memiliki sejumlah fungsi yaitu dalam menjaga ketahanan terhadap penyakit, respirasi, ion dan regulasi osmotik, gerak, reproduksi dan komunikasi. Lebih lanjut disebutkan pula bahwa mucus dari ikan mengandung berbagai senyawa biologis aktif seperti lisozim, lektin, enzim proteolitik, flavoenzim, imunoglobulin, protein C-reaktif, dan peptida antimikroba yang konstitutif untuk memberikan perlindungan untuk ikan dari potensi mikroba patogen dan parasit (Wei, Xavier, \& Marimuthu, 2010).

Aktivitas antimikroba pada mucus dari beberapa ikan air tawar telah banyak dilakukan namun aktivitas antimikroba tersebut sangat bervariasi pada beberapa spesies. Hal ini seperti yang telah ditunjukkan pada beberapa penelitian sebelumnya bahwa aktivitas antimikroba pada mucus ikan air tawar hanya dilakukan pada ikanikan introduksi seperti ikan Nila (Tilapia hornorum) dan ikan Lele (Channa batracus) (Wei, Xavier, \& Marimuthu, 2010). Dengan demikian kajian tentang aktivitas antimikoba pada ikan-ikan native masih sangat minim sehingga perlu dilakukan eksplorasi lebih lanjut tentang potensi antimikroba pada mucus ikan-ikan native khususnya di perairan Danau Limboto.

\section{Material dan Metode}

Alat yang digunakan adalah autoklaf, laminar air flow, aquarium, aerator, sentrifuge, microtube, spektrofotomer, shakter incubator. Bahan yang digunakan adalah mucus ikan-ikan native (Stiphodon sp dan Giuris cf. margaritacea), S. aureus, V.alginolyticus, Nutrient Broth, aquadest, asam asetat 3\%, Muller Hilton Agar, antibiotik Chlorampenicol.

Metode yang digunakan adalah metode eksperimen dengan objek penelitian adalah mucus ikan Stiphodon sp (Manggabai) dan Giuris of. margaritacea (Hulu’u) .

\section{Prosedur Penelitian}

\section{Aklimatisasi}

Ikan-ikan native yang diperoleh dari Perairan Danau Limboto diletakkan dalam wadah untuk diaklimatisasi selama 1 minggu. Selama periode ini ikan diberi pakan secara adlibitum.

\section{Koleksi Mucus Epidermal}

Setelah proses aklimatisasi ikan-ikan native dipindahkan kedalam kantong polietilen steril kemudian digoyangkan ke samping kiri kanan selama 10 sampai 20 menit dan dilakukan secara berulang selama ikan masih memiliki mucus yang cukup untuk diambil (Wei, Xavier, \& Marimuthu, 2010). Setelah selesai dilakukan pengambilan mucus, ikan dikembalikan ke tempat penampungan. 
Sampel mucus yang diperoleh dari ikan kemudian diletakkan pada gelas kimia steril dan diberi label untuk selanjutnya disimpan dalam lemari es pada suhu $4^{\circ} \mathrm{C}$.

\section{Ekstraksi Mucus Epidermal}

Mucus ikan-ikan native diekstraksi dengan menggunakan aquadest dan asam asetat $3 \%$. Apabila mucus ikan yang dihasilkan sebanyak 40 $\mathrm{ml}$, maka larutan asam asetat yang ditambahkan juga sebanyak $40 \mathrm{ml}$. Setelah tercampur, diletakkan diatas air mendidih selama 5 menit. Campuran mucus dan larutan asam asetat kemudian didinginkan dalam es dan disentrifugasi pada 18.000 rpm selama 35 menit pada suhu $4^{\circ} \mathrm{C}$. Supernatan yang terbentuk selanjutnya diambil dengan menggunakan mikropipet dan disimpan dalam gelas kimia serta disimpan pada suhu $4^{\circ} \mathrm{C}$.

\section{Pembuatan Starter Bakteri Uji}

Media NB (Nutrient Broth) dilarutkan sebanyak 0,2 gr ke dalam $25 \mathrm{ml}$ aquadest. Kemudian sterilkan dengan menggunakan autoklaf pada suhu $121^{\circ} \mathrm{C}$ selama 15 menit, kemudian tuangkan ke dalam Erlenmeyer. Mengambil satu ose biakan murni bakteri uji dan dibiakkan kedalam $25 \mathrm{ml}$ Nutrient Broth (NB). Kemudian diinkubasi pada shaker incubator selama $2 \times 24$ jam pada suhu $37^{\circ} \mathrm{C}$ dengan kecepatan $160 \mathrm{rpm}$.

\section{Uji Aktivitas Antibakteri}

Dalam pengujian kepekaan mikroba, terlebih dahulu starter masing-masing mikroba diukur kekeruhannya dengan menggunakan spektrofotometer pada panjang gelombang $580 \mathrm{~nm}$ dengan nilai Optical Density (OD) 0,6 Suspensi mikroba kemudian diinokulasi ke dalam cawan petri sebanyak $1 \mathrm{ml}$ dengan menggunakan mikropipet. Selanjutnya, ke dalam cawan dimasukkan media steril yang telah didinginkan sampai $45^{\circ} \mathrm{C}$ sebanyak $30 \mathrm{ml}$, dengan metode pour plate.

Uji aktivitas antibakteri ini menggunakan metode diffusion test (Kirby-Bauer), yaitu dengan cara merendam cakram blank dalam ekstrak mucus ikan selama 30 menit. Cakram tersebut diangkat kemudian diletakkan dalam media Nutrien Broth yang sudah terisi biakan bakteri dengan menggunakan pinset dan sebagai kontrol positif digunakan cakram yang berisi anbiotik chlorampenicol. Setelah itu, cawan-cawan diinkubasi selama 24 jam dengan suhu $37^{\circ} \mathrm{C}$. Setelah masa inkubasi dilakukan pengukuran diameter zona hambat atau zona bening yang terbentuk diukur dengan menggunakan jangka sorong.

\section{Teknik Pengumpulan Data}

Teknik pengumpulan data dalam penelitian ini adalah dengan mengukur zona hambat. Untuk memperoleh data yang diperlukan dalam penelitian dilakukan pengamatan langsung pada objek yang diteliti dengan melihat diameter zona hambat (zona bening) yang terbentuk kemudian dilakukan pengukuran dengan menggunakan jangka sorong. Apabila zona hambat yang terbentuk berukuran kurang dari $5 \mathrm{~mm}$, maka aktivitas penghambatannya dikategorikan lemah. Apabila zona hambat berukuran 5-10 mm dikategorikan sedang, 10-19 mm dikategorikan kuat dan $20 \mathrm{~mm}$ atau lebih dikategorikan sangat kuat (Vineetha, Vignesh, \& Sridhar, 2015).

\section{Hasil Dan Pembahasan}

Penelitian ini menggunakan mucus yang di ekstraksi dengan dua cara yakni dengan menggunakan pelarut aquadest (air) dan pelarut asam. Penggunaan pelarut asam bertujuan untuk memperoleh peptida/protein dasar yang terkandung dalam mucus. Sementara penggunaan pelarut air bertujuan untuk mengektraksi komponenkomponen kimiawi dalam mucus yang terlarut air seperti protease, lisozim dan glikoprotein (Wei, Xavier, \& Marimuthu, 2010). Diameter zona hambat yang terbentuk (Tabel 1).

Mucus yang di ekstraksi dengan pelarut aquades, diameter zona hambat yang tertinggi untuk bakteri uji Staphylococus aureus ditemui pada mucus ikan Giuris cf. margaritace. dengan diameter zona hambat yang terbentuk sebesar 7,45 mm, dan terendah pada ikan Stiphodon sp. sebesar 7.42. Sebaliknya dengan mucus yang di ekstraksi dengan pelarut asam, zona hambat tertinggi ditemui pada Stiphodon sp dengan zona hambat sebesar 8,67 $\mathrm{mm}$ dan terendah pada ikan Giuris cf. margaritacea dengan zona hambat sebesar $7.15 \mathrm{~mm}$.

$\begin{array}{ccr}\text { Selanjutnya aktivitas } & \text { antibakteri } \\ \text { tertinggi untuk } & \text { bakteri } & \text { Vibrio }\end{array}$ alginolyticus dengan pelarut aquades ditemukan pada Stiphodon sp. dengan diameter $6.85 \mathrm{~mm}$ dan 
terendah pada ikan Giuris cf. margaritacea sebesar $6.08 \mathrm{~mm}$. Sebaliknya untuk mucus yang di ekstraksi dengan pada pelarut asam aktivitas tertinggi ditemui pada Giuris cf. margaritacea sebesar $8,32 \mathrm{~mm}$ dan terendah pada ikan Stiphodon sp. sebesar $7.57 \mathrm{~mm}$.

Dengan demikian dapat dilihat bahwa aktivitas antibakteri yang ditemui pada penelitian ini berada pada kriteria sedang $(5-10 \mathrm{~mm})$ berdasarkan kriteria yang (Vineetha, Vignesh, \& Sridhar, 2015 ).

Mucus epidermal pada ikan sebagai salah satu bagian dari sisten kekebalan bawaan memainkan berbagai peran penting diantaranya dalam fungsi respirasi, komunikasi, osmoregulasi, ekskresi, reproduksi hingga resistensi terhadap penyakit (Islam, Hossain, Islam, \& Shoumo Khondoker, 2014). Peran mucus terhadap resisten penyakit dilakukan melalui penyediaan hambatan fisikkimiawi antara organisme dengan lingkungannya (Subramanian, Ross, \& MacKinnon, 2008), selain itu lapisan mucus epidermal juga menjadi tempat pertama interaksi sebagai besar bakteri berpotensi patogen dengan inangnya (Hiwarale, et al., 2016).

Tabel 1. Diameter zona hambat (mm)

\begin{tabular}{lcccc}
\hline \multirow{2}{*}{ Spesies Ikan } & \multicolumn{2}{c}{ Staphylococcus aureus } & \multicolumn{2}{c}{ Vibrio alginolyticus } \\
\cline { 2 - 5 } & Asam & Aquadest & Asam & Aquadest \\
\hline $\begin{array}{l}\text { Stiphodon sp. (Manggabai) } \\
\begin{array}{l}\text { Giuris cf. margaritacea (Hu- } \\
\text { lu'u) }\end{array}\end{array}$ & 8.67 & 7.42 & 7.57 & 6.85 \\
\hline
\end{tabular}

Aktivititas antibakteri pada mucus epidermal ikan disebabkan oleh berbagai senyawa antibakteri seperti peptida antimikroba, lisozim, lektin, protease dan glikoprotein (Kuppulakshmi et al. 2008; Balasubramanian et al. 2012; Barnes et al. 2003). Beberapa penelitian yang telah dilakukan menunjukkan adanya aktivitas antibakteri dari beberapa mucus epidermal ikan diantaranya Salvelinus alpinus, S. fontinalis, Cyprinus carpio sub sp. koi, Morone saxatilis, Melanogrammus aeglefinus dan Myxine glutinosa (Subramanian et al. 2008); Channa striatus (Wei et al. 2010); Channa punctatus dan Cirrhinus mrigala (Kuppulakshmi et al. 2008); Cyprinidae (Islam et al. 2014); Catla catla, Hypophtahalmicthys molitrix, Labeo rohita dan Ctenopharyngodon idella (Balasubramanian et al. 2012)

Hasil penelitian ini menunjukkan bahwa mucus epidermal yang diekstraksi dari ikan Stiphodon sp (Manggabai) dan ikan Giuris of. margaritacea (Hulu'u) memiliki aktivitas antibakteri dengan kriteria sedang terhadap bakteri Staphylococcus aureus dan Vibrio alginolyticus. Hal ini kemungkinan disebabkan oleh adanya peptida antimikroba yang bekerja melalui interaksi elektrostatik secara negatif dengan fosfolipid pada membran sel bakteri yang diikuti oleh kerusakan fisik (Andreu \& Rivas, 1998). Lebih lanjut peptida



dermaseptin, cerotoxin dan magainin bekerja melalui ikatan dengan membran fosfolipid pada permukaan bakteri yang kaya akan muatan ion negatif dan menyebabkan kandungan intrasel mengalami lisis (Kuppulakshmi, Prakash, Gunasekaran, \& Sarojini, 2008); (Zasloff, 2002 ).

Aktivitas antibakteri yang ditemui pada penelitian ini juga kemungkinan disebabkan oleh enzim-enzim hidrolase seperti lisozim serta protease (serin, sistein dan metalloprotease), tripsin dan glikoprotein (Barnes \& Lightfoot, 2005); (Wei, Xavier, \& Marimuthu, 2010); (Balasubramanian, Rani, Prakash., Prakash, \& Senthilraja, 2012). Enzim-enzim dalam mucus epidermal bekerja melalui aktivasi gen-gene yang mengkode peptida antimikroba serta protein komplementer maupun dengan mekanisme-mekanisme yang melibatkan turunan AMPs seperti pembukaan saluran atau pori serta gangguan terhadap membran sitoplasmi, penghambatan pada pembentukan dinding sel dan asam nukleat (Subramanian, Ross, \& MacKinnon, 2008).

Adanya perbedaan aktivitas antibakteri pada kedua mucus ikan yang diuji kemungkinan disebabkan oleh perbedaan kandungan kimiawi mucus epidermal maupun jumlah sekresi mucus pada setiap ikan uji. Perbedaan kandungan kimia mucus epidermal disebabkan oleh berbagai faktor diantaranya salinitas, $\mathrm{pH}$,penanganan stres maupun 
tahap perkembangan serta kedewasaan. Sementara perbedaan jumlah sekresi mucus epidermal dapat disebabkan oleh struktur tubuh ikan uji. Ikan dengan sedikit sisik mampu memproduksi mucus lebih banyak untuk proteksi dibandingkan ikan dengan sisik yang lebih banyak (Subramanian, Ross, \& MacKinnon, 2008).

\section{Simpulan}

Mucus ikan Stiphodon sp (Manggabai) dan Giuris cf. margaritacea (Hulu'u) memiliki aktivitas antibakteri terhadap bakteri Staphylococcus aureus dan Vibrio alginolyticus dengan kriteria sedang.

\section{Ucapan Terimakasih}

Penulis menyampaikan terimakasih kepada pihak-pihak yang telah membantu dan mendukung dalam penelitian ini, antara lain Lembaga Penelitian dan Pengabdian Masyarakat Universitas Negeri Gorontalo dan Jurusan Biologi, Fakultas Matematika dan Ilmu Pengetahuan Alam.

\section{Daftar Pustaka}

Andreu, D., \& Rivas, L. (1998). Animal Antimicrobial Peptides: An Overview. Biopolymers (Peptide Science), Vol. 47, 415-433.

Aydalina, R. V. (2015). Variasi Morfologis dan Genetik Anggota Famili Eleotridae di Danau Tondano dan Limboto serta Sungai Tapodu dan Bolango, Sulawesi Bagian Utara . Jogjakarta, Indonesia: UGM Press .

Balasubramanian, S., Rani, B., Prakash., A., Prakash, M., \& Senthilraja, P. (2012). Antimicrobial properties of skin mucus from four freshwater cultivable Fishes (Catla catla, Hypophthalmichthys molitrix, Labeo rohita and Ctenopharyngodon idella) . African Journal of Microbiology Research, Vol. 6(24), pp. 5110-5120.

Barnes, S.-J., \& Lightfoot, P. C. (2005). Formation of Magmatic Nickel Sulfide Ore Deposits and Processes Affecting Their Copper and Platinum Group Element Contents . Society of Economic Geologists, Inc., 1-36.

Hiwarale, D. K., Khillare, Y. K., Khillare, K., Wagh, U., Sawant, J., \& Magare, M. (2016). Assessment of antimicrobial properties of fish mucus . World Journal Of Pharmacy and Pharmaceutical Sciences, Vol 5, Issue 5, 666-672.

Islam, M., Hossain, M., Islam, S., \& Shoumo Khondoker, A. K. (2014). Competitive antibacterial activity of two Indian major carps and two Chinese carps fish mucus against common pathogenic bacteria at aquaculture pond. International Journal of Fisheries and Aquatic Studies, Vol 2(2): 158-162.

Kuppulakshmi, C., Prakash, M., Gunasekaran, G., \& Sarojini, S. (2008). Antibacterial properties of fish mucus from Channa punctatus and Cirrhinus mrigala. European Review for Medical and Pharmacological Sciences, Vol 12: 149-153.

Subramanian, S., Ross, N. W., \& MacKinnon, S. L. (2008). Comparison of antimicrobial activity in the epidermal mucus extracts of fish. Comparative Biochemistry and Physiology, Part B (150) : 85-92.

Suwanto, A., Harahap, T. N., Manurung, H., Rustadi, W. C., Nasution, S. R., Suryadiputra, I. N., \& Sualia, I. (2011). Profil 15 Danau Priortas Nasional . Jakarta, Indonesia: Kementerian Lingkungan Hidup .

Vineetha, N., Vignesh, R., \& Sridhar, D. (2015 ). Preparation, Standardization of Antibiotic Discs and Study of Resistance Pattern for First-Line Antibiotics in Isolates from Clinical Samples. International Journal of Applied Research, Vol 1(11): 624-631 . 
Wei, O. Y., Xavier, R., \& Marimuthu, K. (2010). Screening of antibacterial activity of mucus extract of Snakehead fish, Channa striatus (Bloch). European Review for Medical and Pharmacological Sciences, Vol 14 : 675-681.

Zasloff, M. (2002 ). Antimicrobial peptides of multicellularorganisms. Nature, VOL 415 : 389395. 